\title{
Role and mechanism of FLNa and UCP2 in the development of cervical cancer
}

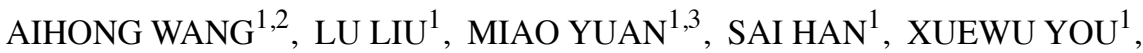 \\ HUI ZHANG ${ }^{4}$, FUHUA LEI ${ }^{5}$ and YOUZHONG ZHANG ${ }^{1}$
}

\begin{abstract}
${ }^{1}$ Department of Obstetrics and Gynaecology, Qilu Hospital of Shandong University, Jinan, Shandong 250012;
${ }^{2}$ Department of Obstetrics and Gynaecology, Feicheng Hospital Affiliated to Shandong First Medical University,

Tai'an, Shandong 271600; ${ }^{3}$ Department of Obstetrics and Gynaecology, The First Affiliated Hospital of

Shandong First Medical University, Jinan, Shandong 250011; ${ }^{4}$ Department of Obstetrics and Gynaecology,

The Second Affiliated Hospital of Shandong First Medical University, Tai'an, Shandong 271000; ${ }^{5}$ Department of Pathology,

Feicheng Hospital Affiliated to Shandong First Medical University, Tai'an, Shandong 271600, P.R. China
\end{abstract}

Received February 26, 2020; Accepted September 11, 2020

DOI: 10.3892/or.2020.7819

\begin{abstract}
Recent studies have reported that filamin A (FLNa) and uncoupling protein 2 (UCP2) are highly expressed in various types of cancer, but little is currently known about their roles in cervical cancer (CC). In the present study, immunohistochemical staining of paraffin sections of cervical tissues was performed in order to compare the differential expression of FLNa, UCP2, p16 and Ki67 between CC and high-grade intraepithelial neoplasia (HSIL). UCP2 and FLNa were knocked down in $\mathrm{CC}$ cell lines to investigate the effects on cell proliferation, cell cycle arrest, apoptosis, migration and invasion. In addition, the present study investigated the expression of cell-associated proteins [extracellular signal-regulated kinase (ERK), phosphorylated (p) ERK, protein kinase B (AKT), p-AKT and B-cell lymphoma-2 (Bcl-2)] and the mRNA levels of cellular proteins such as Ras, matrix metalloproteinase (MMP)-2 and MMP-9. FLNa and UCP2 expression levels were significantly higher in CC tissues than in HSIL tissues, with no significant differential expression of p16 or Ki67. UCP2 expression was significantly different in patients with clinical stage II or higher or lymph node metastasis
\end{abstract}

Correspondence to: Dr Youzhong Zhang, Department of Obstetrics and Gynaecology, Qilu Hospital of Shandong University, 107 Wenhua Xi Road, Jinan, Shandong 250012, P.R. China

E-mail: zhangyouzhong@sdu.edu.cn

Abbreviations: FLNa, filamin A; UCP2, uncoupling protein 2; $\mathrm{CC}$, cervical cancer; NC, normal cervix; LSIL, low-grade squamous intraepithelial lesion; HSIL, high-grade intraepithelial neoplasia; MAPK, mitogen-activated protein kinase; ERK, extracellular signal-regulated kinase; AKT, protein kinase B; MMP, matrix metalloproteinase; Bcl-2, B-cell lymphoma-2

Key words: FLNa, UCP2, cervical cancer, diagnosis, proliferation, apoptosis, migration, invasion compared with in other patients with cervical cancer. FLNa or UCP2 knockdown slowed or decreased SiHa and HeLa cell proliferation, migration and invasion, with no significant change in apoptosis, and downregulated the protein levels of p-ERK1/2, and the mRNA levels of Ras, MMP-2 and MMP-9. UCP2 knockdown arrested the cell cycle at the $\mathrm{G}_{2}$ phase in $\mathrm{SiHa}$ and HeLa cells, while FLNa knockdown arrested the cell cycle at the $\mathrm{G}_{2}$ phase in HeLa cells. The results of the present study revealed that FLNa and UCP2 play roles in the development and progression of CC via the Ras/MAPK/ERK signalling pathway. FLNa and UCP2 are superior to p16 and Ki67 for early prediction of CC, indicating that FLNa and UCP2 may be used for the early diagnosis of CC. UCP2 may be used to predict the prognosis of CC.

\section{Introduction}

Cervical cancer (CC) is a common malignant gynaecological tumour. In 2015, worldwide data showed that CC was the second most common type of cancer (second only to breast cancer) among women in developing countries (1). In 2018, $8,622,539$ cases of cancer were newly diagnosed in women worldwide, and cancer-associated mortality among women reached 4,169,387 cases, where CC (7.5\%) was the fourth leading cause of cancer mortality after breast cancer (15.0\%), lung cancer (13.8\%), and colorectal cancer (9.5\%) (2). In China, the prevalence of $\mathrm{CC}$ is 28.2 per 1,000 women aged 30-44 years (3). Given the prevalence of CC, identifying improved treatment methods for patients at different stages is important. Early CC (stage IA) is usually treated with surgery, and advanced CC (stage IIB-IV) is usually treated with non-surgical options. For intermediate-stage CC (stages IB and IIA) (4), no consensus on the optimal treatment has been established, and the majority of patients undergo surgery or radiotherapy; however, currently available tests cannot reliably predict risk factors in these patients. If such patients undergo surgery and risk factors are confirmed during the operation, radiotherapy will be required after surgery. Numerous studies 
have demonstrated a high incidence of complications following radical surgery combined with radiotherapy (5-9). Every effort should be made to avoid radical surgery combined with pelvic radiotherapy. These patients are not recommended to receive surgery, and at-risk patients may benefit more from chemoradiotherapy. Proper preoperative selection of non-surgical treatment over unnecessary surgery will greatly improve the prognosis $(6,8-10)$. Hence, high-risk predictors must be identified to enable stratified management. Filamin A (FLNa) can be used as a predictor of chemotherapy sensitivity and as a biomarker of prognosis (11), and uncoupling protein 2 (UCP2) can be used as an indicator of chemotherapy sensitivity in patients with advanced CC (12). The present study focused on FLNa and UCP2 and investigated their expression levels in $\mathrm{CC}$, their roles in the development and progression of $\mathrm{CC}$, and their value for early diagnosis and prognosis prediction of $\mathrm{CC}$.

As a non-muscular actin-binding protein and an important scaffolding protein, FLNa interacts with a number of proteins involved in cell signalling and cytoskeletal reorganization, and is also regulated by phosphorylation (13). FLNa is widely distributed in the cytoplasm and is involved in the adhesion between cells. FLNa plays roles in signal transduction and protein sorting $(14,15)$. Increased or decreased FLNa expression contributes to conditions such as inflammation and cancer $(14,15)$. FLNa is aberrantly expressed or mutated in numerous different types of cancer, such as breast cancer, colon cancer, melanoma and prostate cancer (16-21).

UCP2 is a member of the mitochondrial UCP family, which is widely distributed throughout the body (22). As a transmembrane transporter of the inner mitochondrial membrane, UCP2 decreases the production of ATP and reactive oxygen species (ROS) by decoupling mitochondrial oxidation and phosphorylation, thereby protecting tissues and organs from oxidative stress (23). Previous studies have demonstrated increased UCP2 expression in numerous malignant tumours, including colon cancer, cholangiocarcinoma, breast cancer and leukaemia (24-27).

To the best of our knowledge, few studies have investigated the roles of FLNa and UCP2 in CC. To detect the mechanisms of FLNa and UCP2 in the development and progression of $\mathrm{CC}$, the present study used paraffin sections of cervical tissues, including normal cervix (NC), low-grade intraepithelial neoplasia (LSIL), high-grade intraepithelial neoplasia (HSIL) and CC tissues, and performed immunohistochemical staining to determine the expression levels of FLNa and UCP2. The expression of FLNa and UCP2 was knocked down in CC cell lines in order to investigate the effects on cancer cell proliferation, cell cycle arrest, apoptosis, migration and invasion. In addition, the present study investigated the effects of interfering with FLNa and UCP2 expression on apoptosis-associated proteins [extracellular signal-regulated kinase (ERK), phosphorylated (p) ERK, protein kinase B (AKT), p-AKT and B-cell lymphoma-2 (Bcl-2)] and the mRNA levels of Ras, matrix metalloproteinase (MMP)-2 and MMP-9 in CC cell lines ( $\mathrm{SiHa}$ and HeLa) with the aim of determining the mechanisms of action underlying FLNa and UCP2 in the development and progression of $\mathrm{CC}$, and their roles in the early diagnosis and prognosis prediction of $\mathrm{CC}$.

\section{Materials and methods}

Tissue samples from patients. In the present study, paraffin sections were collected from 33 patients with $\mathrm{NC}, 33$ patients with LSIL, 40 patients with HSIL and 45 patients with CC among patients $(47.51 \pm 11.41$ years) treated at Feicheng People's Hospital, (Tai'an, China), between January 2010 and December 2019. The tissues were cut into $4-\mu \mathrm{m}$ sections and $0 \%$ neutral buffer formalin solution was used to fix the samples at room temperature for 24-48 h. The clinical stage was determined according to the 2018 International Federation of Gynecology and Obstetrics (FIGO) staging guidelines (4). Patient age, previous human papilloma virus (HPV) test results, thyrocalcitonin levels, colposcopy findings, and pathology findings were recorded. For each tissue collection, a written consent from the subject was obtained. The present study was approved by the Ethics Committee of Qilu Hospital (approval no. KYLL-2017-560).

Cell lines and cell culture. Human CC cell lines (C33A, SiHa, HeLa, CaSKi, ME-180 and HH-8) and HUCEC cells (normal human cervical epithelial cells), which were used as a control, were provided by Shanghai Meixuan Biotechnology Co., Ltd. Cells were cultured in 90\% Dulbecco's Modified Eagle's Medium (DMEM) (high glucose; H) $+10 \%$ foetal bovine serum (FBS) (Hyclone; Cytiva). Cells were transferred under sterile conditions, seeded into $8-10 \mathrm{ml}$ of complete medium $(90 \%$ DMEM $[\mathrm{H}]+10 \% \mathrm{FBS})$, and cultured at $37^{\circ} \mathrm{C}$ and $5 \% \mathrm{CO}_{2}$ in an incubator. The $\mathrm{SiHa}$ and $\mathrm{HeLa}$ cell lines, which have high FLNa and UCP2 expression levels, were selected for the subsequent experiments.

Antibodies and reagents. The following antibodies were used for immunofluorescence staining: Anti-GAPDH (1:5,000; cat. no. Ab8245; Abcam); anti-UCP2 (1:100; cat. no. 11081-1-AP; ProteinTech Group, Inc.) and anti-FLNa (1:100; cat. no. ab76289; Abcam). The antibodies were used to detect UCP2 and FLNa expression in different CC cell lines.

The following antibodies were used for immunohistochemical staining: Anti-UCP2 (1:200; cat. no. 11081-1-AP; ProteinTech Group, Inc.), anti-FLNa (1:200; cat. no. ab76289; Abcam), anti-P16 (1:200; cat. no. 10883-1-AP; ProteinTech Group, Inc.), and anti-Ki67 (1:1,000; cat. no. ab92742; Abcam).

The following primary antibodies were used for western blotting of relevant proteins: Anti-UCP2 (1:1,000; cat. no. 11081-1-AP; ProteinTech Group, Inc.), anti-FLNa (1:1,000; cat. no. ab76289; Abcam), anti-GAPDH (1:5,000; cat. no. ab8245; Abcam), anti-ERK1/2 (1:1,000; cat. no. 4695; Cell Signaling Technology, Inc.), anti-P-ERK1/2 (1:1,000; cat. no. 4370; Cell Signaling Technology, Inc.), anti-AKT1 (1:1,000; cat. no. ab227100; Abcam), anti-P-AKT1 (1:10,000; cat. no. ab81283; Abcam), and anti-BCL-2 (1:1,000 cat. no. ab32124; Abcam).

Western blotting. After the cell samples were fully lysed using Lysis Buffer (Beyotime Institute of Biotechnology), they were centrifuged at $12,000 \times \mathrm{g}, 4^{\circ} \mathrm{C}$ for $5 \mathrm{~min}$, and part of the supernatant was collected for protein determination using the bicinchoninic acid (BCA) method. 
For the western blotting, the protein was separated via SDS-PAGE (10 and 12\% gels), and the concentration was adjusted to $1 \mathrm{mg} / \mathrm{ml}$, the protein quality was $20 \mu \mathrm{g}$, and the volume was $20 \mu 1$ per lane. Before separating the proteins on a gel, a standard curve was drawn according to the optical density (OD) value and the standard protein concentration to calculate the total protein concentration in the sample. After transferring the sample solution, the membrane was blocked at room temperature for $2 \mathrm{~h}$., using 1\% BSA (Roche Diagnostics). The membrane was removed and then washed with tris-buffered saline Tween-20 (TBST) on a shaking table for $5 \mathrm{~min}$, 3 times. In an incubation bag, the primary antibodies (FLNa and UCP2) were diluted with sealing solution and incubated overnight at $4^{\circ} \mathrm{C}$. The film was washed with TBST for $5 \mathrm{~min}$, 3 times, and then the sheep anti-rabbit secondary antibody (1:5,000; cat. no. SA00001-2 Jackson ImmunoResearch Laboratories, Inc.) horseradish peroxidase-conjugated was added and BCA Protein Quantitation kit (Beyotime Institute of Biotechnology) was used.

Immunofluorescence. The SiHa and HeLa cells were blocked with 3\% BSA-PBS (Roche 735094) for $30 \mathrm{~min}$ at room temperature. The present study used anti-UCP2 and anti-FLNa as primary antibodies and FITC [Fluorescein (FITC)-conjugated Affinipure Goat Anti-Rabbit IgG; 1:50; cat. no. SA00003-2; ProteinTech Group, Inc.] as a secondary antibody. The cell samples were fixed in $4 \%$ precooled paraformaldehyde at room temperature for $15 \mathrm{~min}$, washed with phosphate-buffered saline (PBS) 3 times ( 3 min each time), and incubated in $0.5 \%$ Triton X-100 for $20 \mathrm{~min}$ at room temperature. Next, diluted antibody solution (in PBS containing 5\% bovine serum albumin) (Hyclone; Cytiva) was added (PBS $0.01 \mathrm{M}$, $\mathrm{pH} 7.4$ was used in the blank control group), and the samples were incubated at $4^{\circ} \mathrm{C}$ overnight. On the next morning, the samples were removed from the refrigerator, placed at room temperature for $15 \mathrm{~min}$, and then washed with PBS $(0.01 \mathrm{M}$, pH 7.4) 5 times ( 5 min each). After removal of any extra PBS, FITC was added, and then DAPI was added, followed by incubation in the dark for $2 \mathrm{~min}$. The nucleus was identified by blue fluorescence microscope (Olympus Corporation; $\mathrm{x} 10$ magnification).

Immunohistochemical staining and evaluation. Antigen retrieval was performed using TE buffer $\mathrm{pH} 9.0$, heating in the microwave on band 3 for $10-15 \min$ ( $700 \mathrm{~W}$ oven), the retrieval solution was allowed to cool at room temperature. Endogenous peroxidase activity was blocked by incubating sections in $3 \% \mathrm{H}_{2} \mathrm{O}_{2}$ solution in $\mathrm{ddH}_{2} \mathrm{O}$ for $10 \mathrm{~min}$ at room temperature. Tissue sections ( $4 \mathrm{~mm}$-thick) were stained with FLNa antibody (diluted in PBS, 1:200) and UCP2 antibody (diluted in PBS, 1:200). The expression of FLNa and UCP2 was evaluated in cancer cells.(DAB Detection Kit, Ventana Medical Systems, Inc)The expression scores were grouped as follows: $0,<10 \%$ positive cells; $1,10-25 \%$ positive cells; $2,26-50 \%$ positive cells; $3,51-75 \%$ positive cells; and $4,>75 \%$ positive cells. The cells were stained with DAB for $40 \mathrm{sec}$ and haematoxylin and eosin for $8 \mathrm{~min}$, both at room temperature, and the staining intensity was rated as 0 , none; 1 , weak; 2 , mild; and 3 , strong. The final score was the product of the quantitative expression score and staining intensity and was denoted as negative
$(0-1)$ or positive $(\geq 2)$. All immunohistochemical results were reported by the pathologists at Feicheng People's Hospital (Tai'an, China) and reviewed by another experienced pathologist. A confocal microscope was used to view the images (Olympus Corporation; x40 and x200 magnification).

Reverse transcription-quantitative PCR (RT-qPCR). The primers (Table I) were designed and synthesized by Shanghai Meixuan Biotechnology Co., Ltd. TRIzol ${ }^{\circledR}$ reagent (Invitrogen; Thermo Fisher Scientific, Inc.) was used to extract the total RNA from $\mathrm{SiHa}$ and $\mathrm{HeLa}$ cells, which was stored at $-80^{\circ} \mathrm{C}$. The total RNA $(2 \mu \mathrm{g})$ was used for the synthesis of cDNA according to a PrimeScript RT Reagent kit with g DNA Eraser. Reverse transcription was performed as $50^{\circ} \mathrm{C}$ for $10 \mathrm{~min}$ ). The fluorophore was provided by Shanghai Meixuan Biotechnology Co., Ltd. (SYBR Premix Ex Taq). The PCR conditions were predenaturation at $95^{\circ} \mathrm{C}$ for $30 \mathrm{sec}$, then 45 cycles of $95^{\circ} \mathrm{C}$ for $5 \mathrm{sec}$ and $60^{\circ} \mathrm{C}$ for $30 \mathrm{sec}$. The data were analysed using the $2^{-\Delta \Delta \mathrm{Cq}}$ relative-expression method (28).

Silencing of the FLNa and UCP2 genes in SiHa and HeLa cells. Small interfering RNA (siRNA) sequences were designed and synthesized by Shanghai Meixuan Biotechnology Co., Ltd. Once the cells reached $40-50 \%$ confluency, the cells were seeded into 24 -well plates and transfected with Lipofectamine ${ }^{\circledR} 2000$ according to the manufacturer's instructions (Thermo Fisher Scientific, Inc.). First, 20 pmol siRNA was dissolved in $50 \mu \mathrm{l}$ Opti-MEM culture medium with free FBS. Then, $1 \mu \mathrm{l}$ Lipofectamine $^{\circledR} 2000$ was dissolved in $50 \mu \mathrm{l}$ Opti-MEM culture medium for $5 \mathrm{~min}$ at room temperature. Finally, the aforementioned two solutions were mixed while resting for $20 \mathrm{~min}$ at room temperature, then $400 \mu \mathrm{lmixed}$ solution was added to each well in the 24-well plates, and the transfection medium was changed to cultured medium (Hyclone; Cytiva) containing 90\% DMEM high sugar and $10 \%$ FBS) after 4-6 h. The cells were extracted for the PCR experiment after $48 \mathrm{~h}$. siRNAs were transfected into cells with Lipofectamine ${ }^{\circledR} 2000$ for $48 \mathrm{~h}$, and then cells were collected for qPCR to analyse the mRNA levels of UCP2 and FLNa. After $48 \mathrm{~h}$, a sequence with good interference was selected for later experiments; a third siRNA was selected to knockdown UCP2, and a second siRNA was selected to knockdown FLNa in HeLa and SiHa cells. Each in vitro experiment was performed three independent times and in three replicates.

Cell proliferation assay. Cell Counting Kit-8 (CCK-8) (Beyotime Institute of Biotechnology) was used to detect cell survival. The absorbance at $450 \mathrm{~nm}$ was measured with a microplate reader (Multiskan 3; Thermo Fisher Scientific, Inc.). The measurement was $5 \times 10^{3} / 100 \mu \mathrm{l}$ for each sample. All experiments were repeated at least three times. The equation used for the calculation of the cell proliferation inhibition rate was as follows: Inhibition ratio $=(\mathrm{OD}$ value of control group-OD value of experimental group)/(OD value of control group-OD value of blank hole) x100\%.

\section{Migration and invasion assays}

Scratch test. The transfected cells were digested and seeded into 6-well plates. Once the cells reached $100 \%$ confluency, the medium was replaced with serum-free medium to starve 
Table I. Primers for mRNA detection of relevant genes.

\begin{tabular}{lccc}
\hline Gene & Species & Forward, 5'-3' & Reverse, 5'-3' \\
\hline hGAPDH & $\mathrm{h}$ & GCACCGTCAAGGCTGAGAAC & TGGTGAAGACGCCAGTGGA \\
RAS & $\mathrm{h}$ & GAGTAGCGCAGTCGCCAAAG & GCTCGGGGTCCAATAGTAGC \\
MMP2 & $\mathrm{h}$ & CGCATCTGGGGCTTTAAACA & GCACTGCCAACTCTTTGTCC \\
MMP9 & $\mathrm{h}$ & TCTATGGTCCTCGCCCTGAA & CATCGTCCACCGGACTCAAA
\end{tabular}

h, human; MMP, matrix metalloproteinase.

the cells overnight. Different siRNAs were transfected into different groups of cells, and the medium was replaced with fresh serum-free medium after 4-6 h. A $100-\mu l$ pipette tip was used to scratch the plates, an image of which was captured and recorded as $0 \mathrm{~h}$. After $48 \mathrm{~h}$, another image was captured to analyse cell confluency relative to that at $0 \mathrm{~h}$. The present study used Image Pro Plus software (version 6.0; Media Cybernetics, Inc.) to test and calculate the distance between the cells. The formula used for the calculation of the cell migration distance was as follows: Cell migration distance $=0 \mathrm{~h}$ intercellular distance-48 h intercellular distance. A confocal microscope was used to detect the cells (Olympus Corporation; x100 magnification).

Transwell assay. A total of $5 \times 10^{4}$ cells were inoculated into a Transwell chamber (BD Biosciences), and $500 \mu \mathrm{l}$ of fresh medium containing $20 \%$ FBS was added to the lower chamber. The chamber was incubated at $37^{\circ} \mathrm{C}$ and $5 \% \mathrm{CO}_{2}$ for $48 \mathrm{~h}$. Next, the cells were fixed in $4 \%$ paraformaldehyde for $10 \mathrm{~min}$, stained with crystal violet solution for $5 \mathrm{~min}$ at room temperature and washed with water until the base membrane was transparent. Lastly, images of the cells were captured using a confocal microscope (Olympus Corporation; x100 magnification), then the cells were counted and analysed.

Cell cycle and apoptosis assays. The transfected cells were washed twice using precooled PBS and then digested in $70 \%$ alcohol at $4{ }^{\circ} \mathrm{C}$ overnight. For cell cycle detection, a cell cycle detection kit was obtained from Beyotime Institute of Biotechnology. A FACSCalibur flow cytometer (BD Biosciences) was used to detect red fluorescence at an excitation wavelength of $488 \mathrm{~nm}$. Appropriate analysis software (FlowJo; version 10; FlowJo LLC) was used for DNA content and light scattering analyses. For apoptosis detection, an Annexin V-FITC apoptosis assay kit was obtained from Beyotime Institute of Biotechnology. Cells were collected and treated as described in the kits and analysed by flow cytometry.

Statistical analysis. SPSS software (version 21.0; IBM Corp.) was used for immunohistochemical staining statistical analysis. The $\chi^{2}$ and Fisher's exact test were performed. For the cell line experiments, all assays were performed in at least triplicate. The results are expressed as the mean \pm SD and analysed by unpaired t-test or one-way ANOVA followed by Tukey's post hoc test, with SPSS software (version 21.0). $\mathrm{P}<0.05$ was considered to indicate a statistically significant difference.

\section{Results}

Expression of FLNa/UCP2 in human cervical cancer tissues and cell lines. To detect the expression levels of FLNa and UCP2 in CC, the present study performed immunohistochemical staining on 33 NC, 33 LSIL, 40 HSIL and 45 CC tissues. Representative images are presented in Fig. 1A. The expression levels of FLNa and UCP2 in CC were rated as the product of the quantitative score and staining intensity $(n=45)$. The scores ranged from 0 to 12 , and scores of $0-1$ were rated as negative, whereas scores $\geq 2$ were rated as positive. The median score of each protein in the tissues was used as the threshold to separate low expression from high expression (Table II). The results show that FLNa and UCP2 were highly expressed in the CC tissues (Table III). The FLNa and UCP2 expression levels were detected by PCR and western blotting in six human CC cell lines (C33A, SiHa, HeLa, CaSKi, ME-180 and HH-8), and HUCEC cells (normal human cervical epithelial cells) as control cells. All experiments were repeated at least three times (Fig. 2A-C). The SiHa and HeLa cell lines, which had the highest FLNa and UCP2 expression levels, were selected for the subsequent experiments. To investigate the expression of FLNa/UCP2 in cells, the present study performed immunofluorescence staining in SiHa and HeLa cells. The immunofluorescence quantitative analysis is presented in (Fig. 2D). It was revealed that FLNa and UCP2 were mainly located in the cytoplasm of CC cells, as determined by immunofluorescence staining (Fig. 2D). According to the results of the present study, FLNa and UCP2 were highly expressed in CC cells. The immunohistochemical staining experiment showed the same results, and thus, SiHa and HeLa cells were selected for the subsequent experiments in order to determine the function of $\mathrm{FLNa} / \mathrm{UCP} 2$ in $\mathrm{CC}$ cell lines.

Associations between the expression of FLNa and UCP2 in $C C$ tissues and clinicopathological factors. To investigate the associations between FLNa/UCP2 expression in CC tissues and clinicopathological factors, the present study analysed age, tumour size, tumour differentiation, clinical stage, lymph node metastasis and histological type of the patients. No significant association was observed between the expression levels of FLNa in $\mathrm{CC}$ and age $(\mathrm{P}=0.714)$, tumour size $(\mathrm{P}=0.064)$, tumour differentiation $(\mathrm{P}=0.317)$, clinical stage $(\mathrm{P}=0.828)$, lymph node metastasis $(\mathrm{P}=0.737)$ or histology $(\mathrm{P}=0.060)$ (all $\mathrm{P}>0.05)$. No significant association was observed between the expression level of UCP2 in $\mathrm{CC}$ and age $(\mathrm{P}=0.276)$, tumour size $(\mathrm{P}=0.194)$, tumour differentiation $(\mathrm{P}=0.064)$ or histology 
Table II. Expression of FLNa and UCP2 in cervical cancer.

\begin{tabular}{lccccc}
\hline & & \multicolumn{2}{c}{ Low expression } & & \multicolumn{2}{c}{ High expression } \\
\cline { 3 - 4 } Protein & Total & Score & $\mathrm{n}$ & Score & $\mathrm{n}$ \\
\hline $\mathrm{UCP2}$ & 45 & $0-1$ & 35 & $2-12$ & 10 \\
FLNa & 45 & $0-6$ & 17 & $9-12$ & 28 \\
\hline
\end{tabular}

FLNa, filamin A; UCP2, uncoupling protein 2.

Table III. Positive expression of FLNa and UCP2 in NC, LSIL, HSIL and CC.

\begin{tabular}{|c|c|c|c|c|c|c|c|c|c|c|c|}
\hline \multirow[b]{3}{*}{ Group } & \multirow[b]{3}{*}{$\mathrm{n}$} & \multicolumn{5}{|c|}{ FLNa expression } & \multicolumn{5}{|c|}{ UCP2 expression } \\
\hline & & \multicolumn{2}{|c|}{ Positive } & \multicolumn{3}{|c|}{$\mathrm{P}$-value } & \multicolumn{2}{|c|}{ Positive } & \multicolumn{3}{|c|}{$\mathrm{P}$-value } \\
\hline & & $\mathrm{n}$ & $\%$ & vs. NC & vs. LSIL & vs. HSIL & $\mathrm{n}$ & $\%$ & vs. NC & vs. LSIL & vs. HSIL \\
\hline $\mathrm{NC}$ & 33 & 8 & 23.3 & N/A & $\mathrm{N} / \mathrm{A}$ & N/A & 0 & 0 & N/A & N/A & N/A \\
\hline LSIL & 33 & 19 & 57.6 & 0.006 & N/A & N/A & 3 & 9.1 & 0.237 & N/A & N/A \\
\hline HSIL & 40 & 24 & 72.5 & 0.002 & 0.834 & N/A & 2 & 5.0 & 0.498 & 0.823 & $\mathrm{~N} / \mathrm{A}$ \\
\hline $\mathrm{CC}$ & 45 & 39 & 86.7 & 0.000 & 0.004 & 0.005 & 10 & 22.2 & 0.011 & 0.124 & 0.023 \\
\hline
\end{tabular}

FLNa, filamin A; UCP2, uncoupling protein 2; NC, normal cervix; LSIL, low-grade squamous intraepithelial lesion; HSIL, high-grade intraepithelial neoplasia; CC, cervical cancer.

A
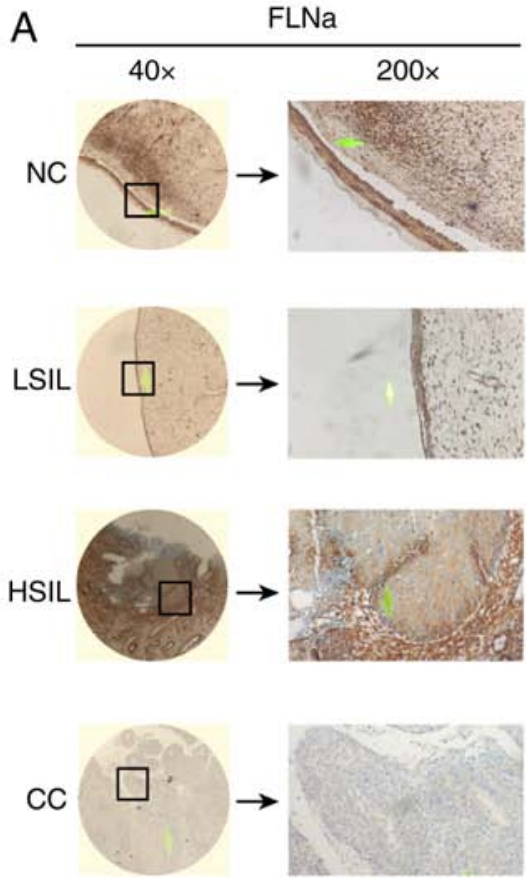
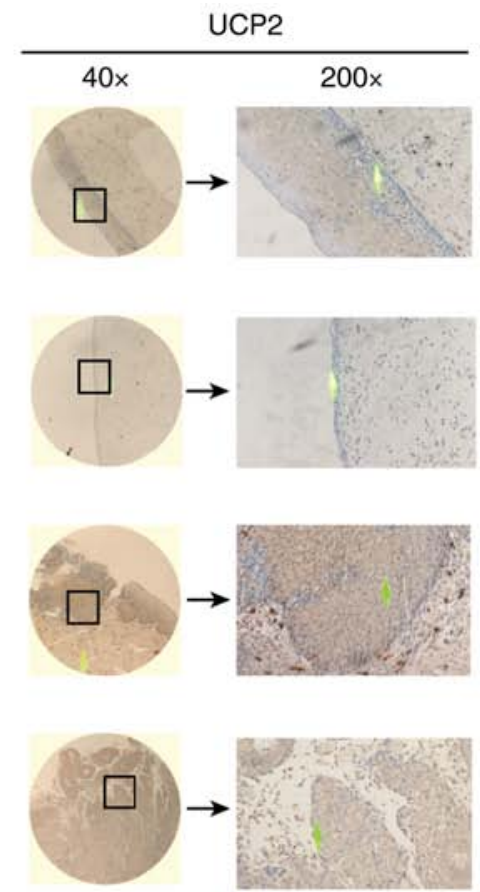

B
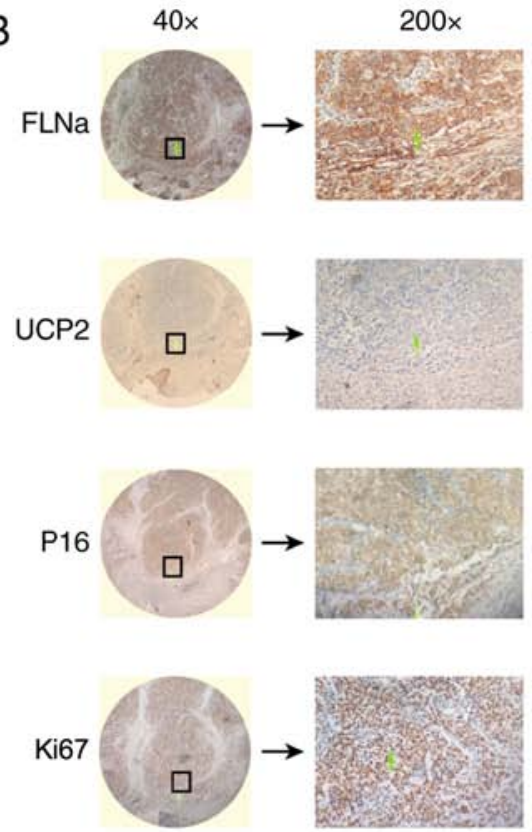

Figure 1. Immunohistochemical staining of FLNa, UCP2, p16 and Ki67 in different groups of cervical tissues. (A) Representative images for the immunohistochemical staining of FLNa and UCP2 in NC, LSIL, HSIL and CC tissues (magnification x40 and x200). (B) Representative images for the immunohistochemical staining of FLNa, UCP2, p16 and Ki67 in CC tissues (magnification x40 and x200). FLNa, filamin A; UCP2, uncoupling protein 2; NC, normal cervix; LSIL, low-grade squamous intraepithelial lesion; HSIL, high-grade intraepithelial neoplasia; CC, cervical cancer.

( $\mathrm{P}>0.999)$. However, significant associations were observed for clinical stage $(\mathrm{P}=0.009)$ and lymph node metastasis $(\mathrm{P}=0.022)$ (both $\mathrm{P}<0.05$ ) (Table IV).
Expression of four immunohistochemical indicators, FLNa, UCP2, p16 and Ki67, in CC tissues. To investigate whether the predictive function of FLNa/UCP2 was better than that of 
A

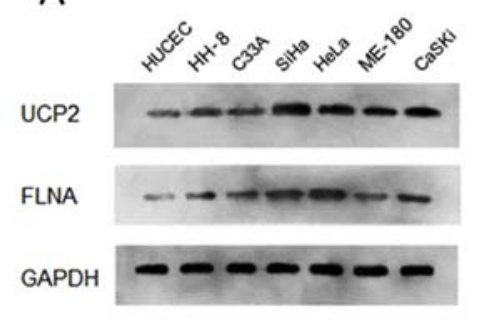

B

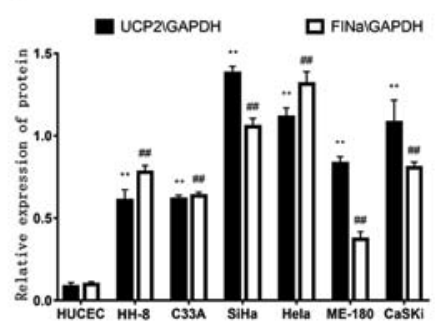

C

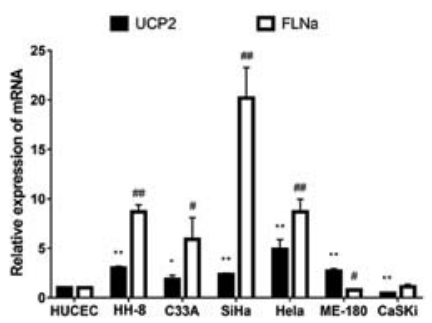

D

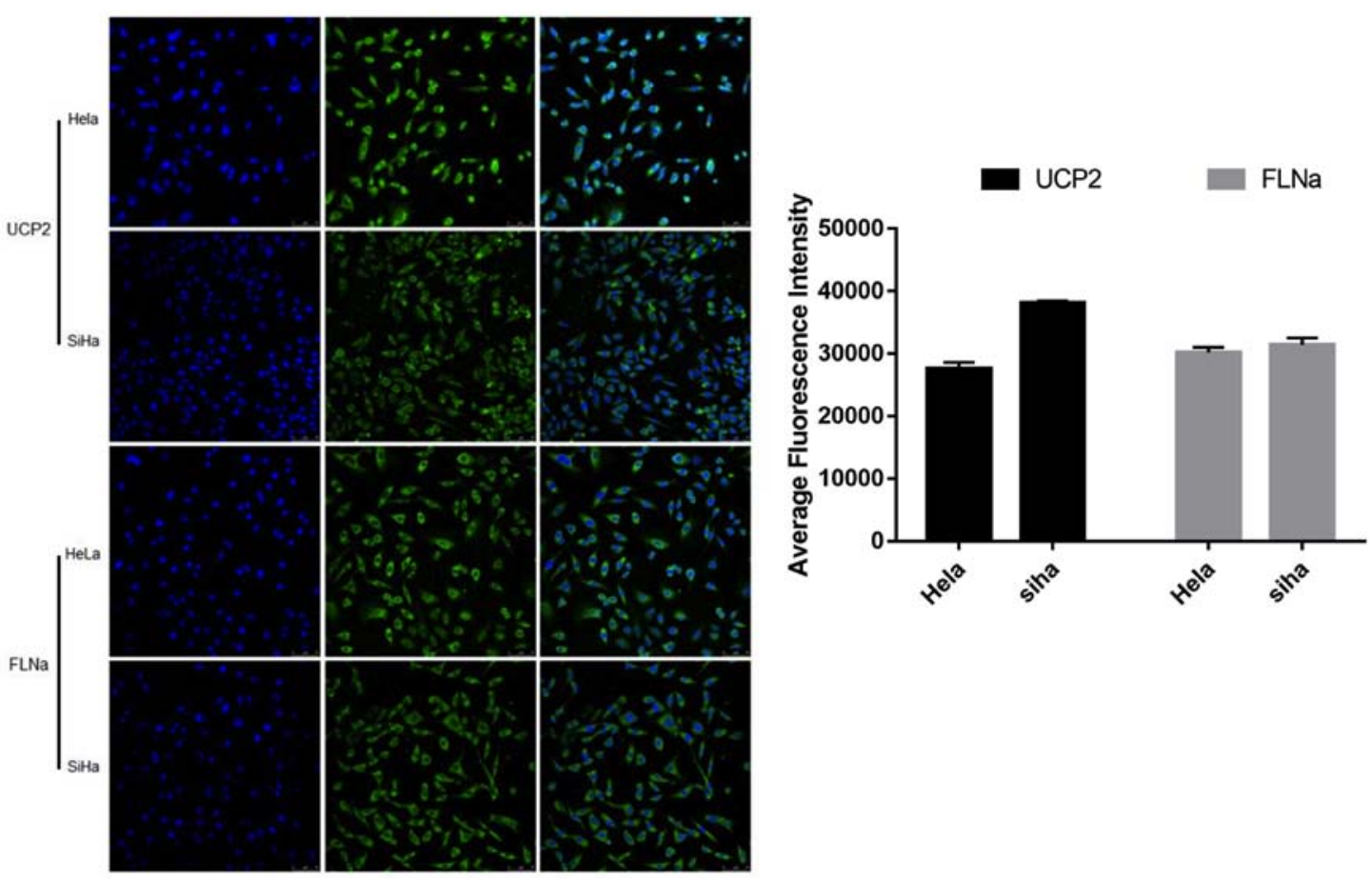

Figure 2. FLNa and UCP2 expression in different CC cell lines. (A) Relative expression of FLNa and UCP2 detected by western blotting in six human CC cell lines (C33A, SiHa, HeLa, CaSKi, ME-180 and HH-8) and HUCEC cells (normal human cervical epithelial cells) as control cells. (B) Quantification of the protein expression levels in (A) compared with the HUCEC cells. (C) Relative expression of FLNa and UCP2 detected by reverse transcription-quantitative PCR in six human CC cell lines (C33A, SiHa, HeLa, CaSKi, ME-180 and HH-8) and in HUCEC cells (normal human cervical epithelial cells) as control cells, compared with the HUCEC cells. (D) Immunofluorescence staining showing that FLNa and UCP2 were mainly located in the cytoplasm of HeLa and SiHa cells. Quantification of the immunofluorescence is shown. ${ }^{*} \mathrm{P}<0.05,{ }^{* * *} \mathrm{P}<0.01,{ }^{\#} \mathrm{P}<0.05,{ }^{* \#} \mathrm{P}<0.01$ vs. FLNa, filamin A; UCP2, uncoupling protein 2 ; CC, cervical cancer.

p16 and Ki-67 in cervical HSIL progression to CC, the present study stained for FLNa, UCP2, P16 and Ki-67 as four CC markers in immunohistochemical staining. The expression levels of these four markers were observed under x200 and $\mathrm{x} 40$ magnification under a confocal microscope (Olympus Corporation). FLNa and UCP2 were primarily stained in the cytoplasm of CC cells as brown or dark-brown particles. The positive rate of FLNa was $86.7 \%$ (39/45), and the positive rate of UCP2 was $22.2 \%$ (10/45). p16 was expressed in the nucleus as brown or dark-brown particles, and the positive rate was $97.8 \%$ (44/45). Ki67 was expressed in the nucleus as brown or dark-brown particles, and the positive rate was $100 \%(45 / 45)$. Representative images are presented in Fig. 1B. The present study compared the positive rates of FLNa, UCP2, p16 and Ki67 between the CC and HSIL tissues (Table V). Significant differences in FLNa $(\mathrm{P}=0.005)$ and $\mathrm{UCP} 2(\mathrm{P}=0.023)$ were observed between HSIL and CC tissues. No significant difference was observed in p16 $(\mathrm{P}=0.917)$ or Ki67 $(\mathrm{P}=0.471)$.
FLNa and UCP2 were superior to p16 and Ki67 for early prediction of progression from HSIL to CC. The present study also analysed the associations between the expression levels of FLNa, UCP2 and p16 in CC and HSIL tissues (Table VI). It was revealed that in the CC tissues, both FLNa and p16 were positively expressed in 39 cases, and neither was expressed in one case $(\mathrm{P}<0.01)$. Both $\mathrm{UCP} 2$ and $\mathrm{p} 16$ were positively expressed in 10 cases, and neither was expressed in one case, indicating a positive association, though this result was not statistically significant $(\mathrm{P}>0.05)$. In HSIL tissues, both FLNa and p16 were positively expressed in 29 cases, and neither were expressed in two cases, but this was not statistically significant $(\mathrm{P}>0.01)$. Both UCP2 and p16 were positively expressed in two cases, and neither was expressed in two cases, but this result was not statistically significant $(\mathrm{P}>0.05)$. The aforementioned analysis indicated that there is an association between the expression levels of FLNa and p16 $(\mathrm{P}<0.01)$. 
Table IV. Association between the expression levels of FLNa and UCP2 and the clinicopathological features of cervical cancer.

\begin{tabular}{|c|c|c|c|c|c|c|c|}
\hline \multirow[b]{2}{*}{ Group } & \multirow[b]{2}{*}{ Total } & \multicolumn{3}{|c|}{ FLNa, $n$} & \multicolumn{3}{|c|}{$\mathrm{UCP} 2, \mathrm{n}$} \\
\hline & & $\begin{array}{c}\text { Low } \\
\text { expression } \\
(n=17)\end{array}$ & $\begin{array}{c}\text { High } \\
\text { expression } \\
(n=28)\end{array}$ & P-value & $\begin{array}{c}\text { Low } \\
\text { expression } \\
(n=35)\end{array}$ & $\begin{array}{c}\text { High } \\
\text { expression } \\
(n=10)\end{array}$ & P-value \\
\hline Age, years & & & & 0.714 & & & 0.276 \\
\hline$\leq 45$ & 17 & 7 & 10 & & 15 & 2 & \\
\hline$>45$ & 28 & 10 & 18 & & 20 & 8 & \\
\hline Diameter of tumour, $\mathrm{cm}$ & & & & 0.064 & & & 0.194 \\
\hline$\leq 4$ & 35 & 16 & 19 & & 29 & 6 & \\
\hline$>4$ & 10 & 1 & 9 & & 6 & 4 & \\
\hline Degree of differentiation & & & & 0.317 & & & 0.064 \\
\hline Low & 28 & 9 & 19 & & 19 & 9 & \\
\hline Moderate or high & 17 & 8 & 9 & & 16 & 1 & \\
\hline Stage & & & & 0.828 & & & 0.009 \\
\hline I & 30 & 11 & 19 & & 27 & 3 & \\
\hline II-III & 15 & 6 & 9 & & 8 & 7 & \\
\hline Lymph node metastasis & & & & 0.737 & & & 0.022 \\
\hline Yes & 13 & 4 & 9 & & 7 & 6 & \\
\hline No & 32 & 13 & 19 & & 28 & 4 & \\
\hline Pathological pattern & & & & 0.060 & & & $>0.999$ \\
\hline $\mathrm{SCC}$ & 40 & 13 & 27 & & 31 & 9 & \\
\hline Adenocarcinoma & 5 & 4 & 1 & & 4 & 1 & \\
\hline
\end{tabular}

FLNa, filamin A; UCP2, uncoupling protein 2; SCC, squamous cell carcinoma.

Table V. Positive expression of FLNa, UCP2, p16 and Ki67 in CC and HSIL.

\begin{tabular}{|c|c|c|c|c|c|c|c|c|c|c|c|c|c|}
\hline \multirow[b]{3}{*}{ Group } & \multirow[b]{3}{*}{ Total, $\mathrm{n}$} & \multicolumn{3}{|c|}{ FLNa } & \multicolumn{3}{|c|}{ UCP2 } & \multicolumn{3}{|c|}{ p16 } & \multicolumn{3}{|c|}{ Ki67 } \\
\hline & & \multicolumn{2}{|c|}{ Positive } & \multirow[b]{2}{*}{ P-value } & \multicolumn{2}{|c|}{ Positive } & \multirow[b]{2}{*}{ P-value } & \multicolumn{2}{|c|}{ Positive } & \multirow[b]{2}{*}{ P-value } & \multicolumn{2}{|c|}{ Positive } & \multirow[b]{2}{*}{$\mathrm{P}$-value } \\
\hline & & $\mathrm{n}$ & $\%$ & & $\mathrm{n}$ & $\%$ & & $\mathrm{n}$ & $\%$ & & $\mathrm{n}$ & $\%$ & \\
\hline HSIL & 40 & 24 & 72.5 & 0.005 & 2 & 5 & 0.023 & 38 & 95 & 0.917 & 39 & 97.5 & 0.471 \\
\hline $\mathrm{CC}$ & 45 & 39 & 86.7 & & 10 & 22.5 & & 44 & 97.8 & & 45 & 100 & \\
\hline
\end{tabular}

FLNa, filamin A; UCP2, uncoupling protein 2; CC, cervical cancer; HSIL, high-grade intraepithelial neoplasia.

Knockdown of FLNa/UCP2 influences cell proliferation, apoptosis and the cell cycle. To investigate the functions and signalling pathways of FLNa and UCP2 in the development and progression of CC, FLNa and UCP2 siRNAs (Table VII) were designed and synthesized to downregulate the expression of FLNa and UCP2 via plasmid transfection, and the knockdown effect was confirmed via western blotting HeLa and SiHa cells with stable, high expression levels of FLNa and UCP2 were used for subsequent experiments. All experiments were repeated at least three times. Based on the qPCR, a third siRNA was selected to knockdown UCP2, and a second siRNA was selected to knockdown FLNa in HeLa and SiHa cells (Fig. 3A and B). To investigate the functions and mechanisms of action underlying UCP2 and FLNa, UCP2 and FLNa expression was knocked down in HeLa and SiHa cells, and the CCK-8 assay was used to analyse cell proliferation. The present study used the cellular proliferation inhibition rate to present the results of the CCK- 8 assays, which demonstrated that cell proliferation was inhibited (Fig. 3C). The present study also used flow cytometry to analyse cell apoptosis, which revealed that following UCP2 and FLNa knockdown in HeLa and $\mathrm{SiHa}$ cells, there was no significant difference in apoptosis compared with the control groups (Fig. 4A). Following UCP2 and FLNa knockdown in HeLa cells and UCP2 knockdown in $\mathrm{SiHa}$ cells, more cells were arrested at the $\mathrm{G}_{2}$ phase. Following UCP2 knockdown in SiHa cells G2 cells content increased. 
Table VI. Co-expression of FLNa, UCP2 and p16 in CC and HSIL.

\begin{tabular}{|c|c|c|c|c|c|c|c|c|c|}
\hline \multirow[b]{2}{*}{ Protein } & \multirow[b]{2}{*}{ Type } & \multirow[b]{2}{*}{$\mathrm{n}$} & \multirow[b]{2}{*}{ Group } & \multicolumn{3}{|c|}{ FLNa } & \multicolumn{3}{|c|}{ UCP2 } \\
\hline & & & & Negative & Positive & $\mathrm{P}$-value & Negative & Positive & P-value \\
\hline \multirow[t]{4}{*}{ p16 } & HSIL & 40 & Negative $(n=2)$ & 2 & 0 & 0.071 & 2 & 0 & 1 \\
\hline & & & Positive $(n=38)$ & 9 & 29 & & 36 & 2 & \\
\hline & $\mathrm{CC}$ & 45 & Negative $(n=1)$ & 1 & 0 & 0.009 & 1 & 0 & 0.599 \\
\hline & & & Positive $(n=44)$ & 5 & 39 & & 34 & 10 & \\
\hline
\end{tabular}

FLNa, filamin A; UCP2, uncoupling protein 2; CC, cervical cancer; HSIL, high-grade intraepithelial neoplasia.

Table VII. FLNa and UCP2 interference sequences.

Sequence, $5^{\prime}-3^{\prime}$

\section{UCP2}

1

2

3

Control 1

FLNa

1

2

3

Control 2

FLNa, filamin A; UCP2, uncoupling protein 2.

Following FLNa knockdown in SiHa cells, no significant cell cycle arrest was observed (Fig. 4B).

Knockdown of FLNa/UCP2 influences cell invasion and migration. The scratch test and Transwell assay were used to detect cell migration and invasion. The results revealed that cell migration (Fig. 3D) and cell invasion were significantly decreased (Fig. 3E) with knockdown of these two proteins.

Knockdown of FLNa/UCP2 influences cell signalling pathway proteins. Western blotting was performed in order to detect the expression levels of relevant proteins (Fig. 5A), including ERK, p-ERK, AKT, p-AKT and Bcl-2. The results showed no significant change in ERK/p-ERK, AKT1 or Bcl-2 levels (Fig. 5D), but p-ERK1/2 (Fig. 5B) and p-AKT1 (Fig. 5C) were downregulated. PCR showed that the mRNA levels of Ras (Fig. 5E), MMP-2 (Fig. 5F) and MMP-9 (Fig. 5G) were decreased.

\section{Discussion}

For decades, population-wide cytology screening for CC in Europe, North America, Australia and New Zealand has contributed to a rapid decline in the prevalence of CC $(29,30)$. In Eastern Europe and Central Asia, however, CC-associated premature mortality continues to rise due to the lack of effective screening and treatment strategies (31). Given the scale of the patient population, prognostic indicators of $\mathrm{CC}$ must be identified to enable stratified management of patients.

The present study showed that the positive rate of FLNa was significantly higher in CC tissues than in NC tissues, contradicting the results of a previous study (32) showing that the positive rate of FLNa was higher in normal prostate tissue than in prostate cancer tissue. This discrepancy may be associated with the different roles of FLNa in cancer cells at different sites and to the different pathological types, and further research is required in order to investigate the mechanism underlying increasing or decreasing FLNa expression levels. The results of the present study showed that the positive rate of UCP2 was significantly higher in $\mathrm{CC}$ tissues than in NC tissues, which is consistent with a study by Horimoto et al (24). Furthermore, the present study revealed that the positive rate of FLNa was $86.7 \%$ (39/45) in CC tissues (positive, $n=39$; negative, $n=6$ ). Among the six tissue samples with negative FLNa expression, two had positive UCP2 expression, indicating that UCP2 was a useful complementary indicator to FLNa and may help to decreased missed diagnoses during screening. Immunohistochemical staining showed that FLNa may be expressed in both CC and HSIL tissues. Thus, a positive screening result suggests high-grade cervical lesions, and that there is an association between the expression levels of FLNa and p16, which is very important for precancer screening, although the absence of negative individuals in the present study was a limitation, and so more data are required. The positive rate of UCP2 was significantly higher in CC tissues than in NC tissues, with no significant difference between NC, LSIL and HSIL tissues. UCP2 is more specific with regard to clinical stage and lymph node metastasis, and positive screening may help predict at-risk patients or advanced clinical stages.

The necessity for surgical treatment should be evaluated in each patient. Non-surgical options (such as radiotherapy) may be more advantageous than surgery. In clinical practice, p16 and Ki67 have been widely used for CC screening. Among high-risk HPV-positive subjects, p16/Ki67 dual staining is 
A

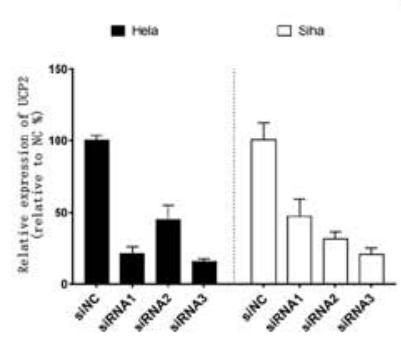

D

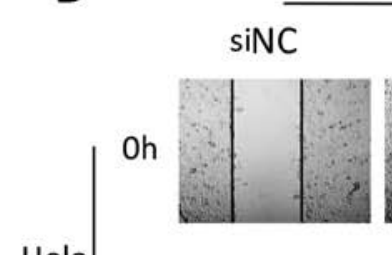

UCP2

Hela

$48 \mathrm{~h}$
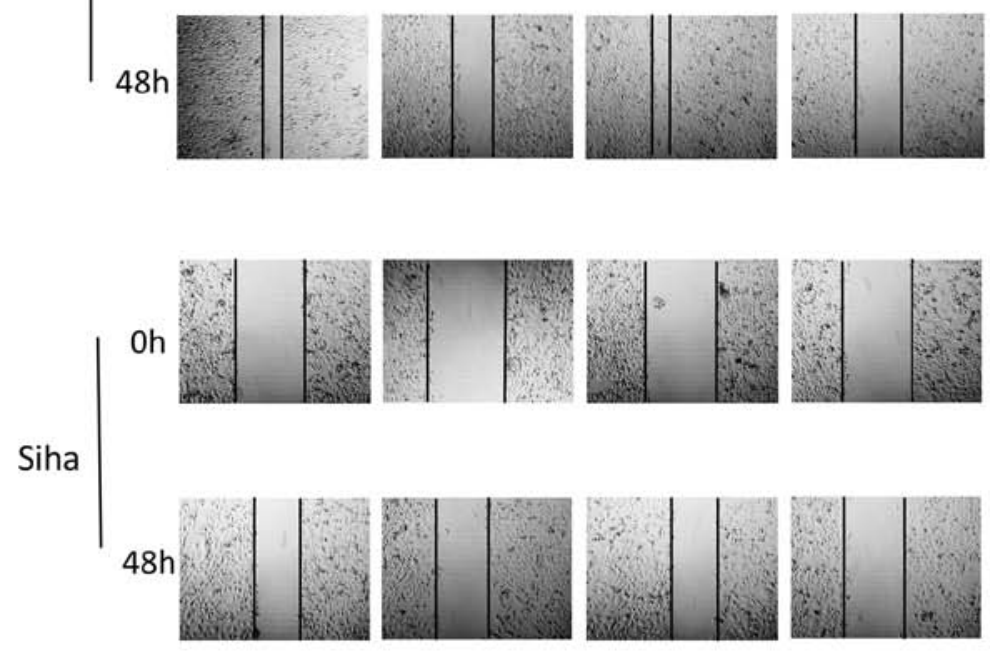

$\mathrm{E}$

Hela

UCP2-siNC
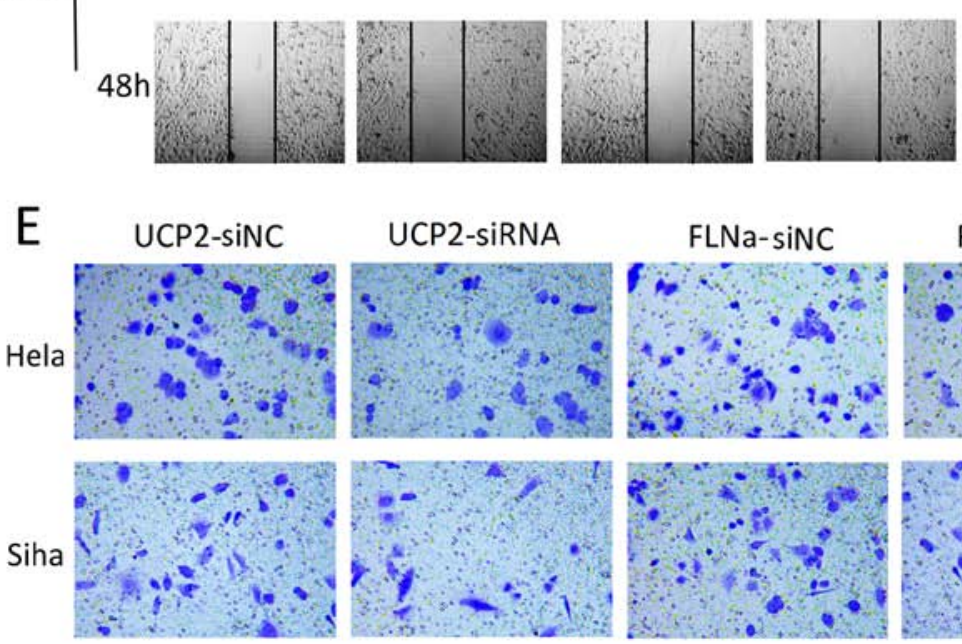

C
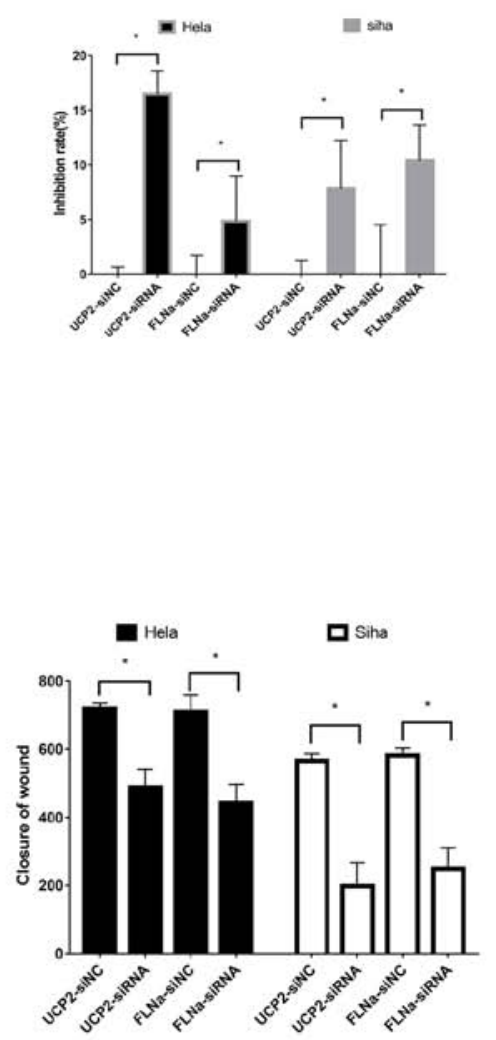

Figure 3. Investigation into the functions of UCP2 and FLNa. (A) Based on quantitative PCR, a third siRNA was selected to knock down UCP2 in HeLa and SiHa cells. (B) Based on quantitative PCR, a second siRNA was selected to knockdown FLNa in HeLa and SiHa cells. (C) CCK-8 analysis of cell proliferation. The present study used the cellular proliferation inhibition rate to present the results of the CCK- 8 assays. Cell proliferation was inhibited. (D) Representative images of cell migration from the 0 and $48 \mathrm{~h}$ timepoints, which was significantly decreased following knockdown of FLNa/UCP2. (E) Representative images of cell invasion, which was significantly decreased following knockdown of FLNa/UCP2. "P<0.05. UCP2, uncoupling protein 2; FLNa, filamin A; siRNA, small interfering RNA; CCK-8, Cell Counting Kit-8; SiNC, small interfering normal control.

more sensitive and specific than thyrocalcitonin for cervical lesion screening (33). In the present study, the positive immunohistochemical staining rates of FLNa, UCP2, p16 and Ki67 were analysed in both CC and HSIL tissues. The results demonstrated significant differential expression of FLNa and UCP2, but not p16 or Ki67, between CC and HSIL. Furthermore, FLNa and UCP2 were superior to p16 and Ki67 for early prediction of progression from HSIL to CC. The positive rates of p16 and Ki67 were extremely high in CC tissues [p16, 97.8\% (44/45); Ki67, 100\% (45/45)], with no significant differential expression between patients with different clinical stages or between those with and without risk factors, potentially due to p16/Ki67 dual staining being advantageous for precancerous screening; however, it cannot be used to predict the prognosis. 


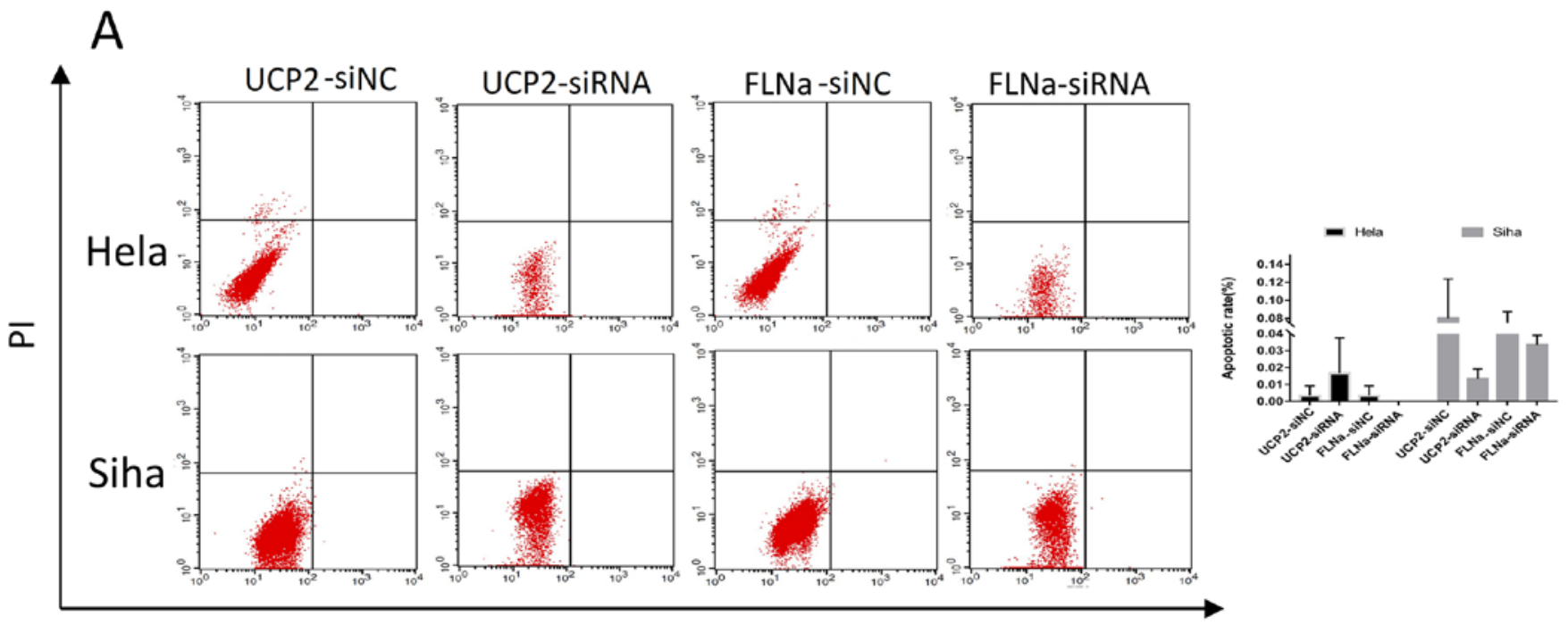

B

Annexin V-FITC
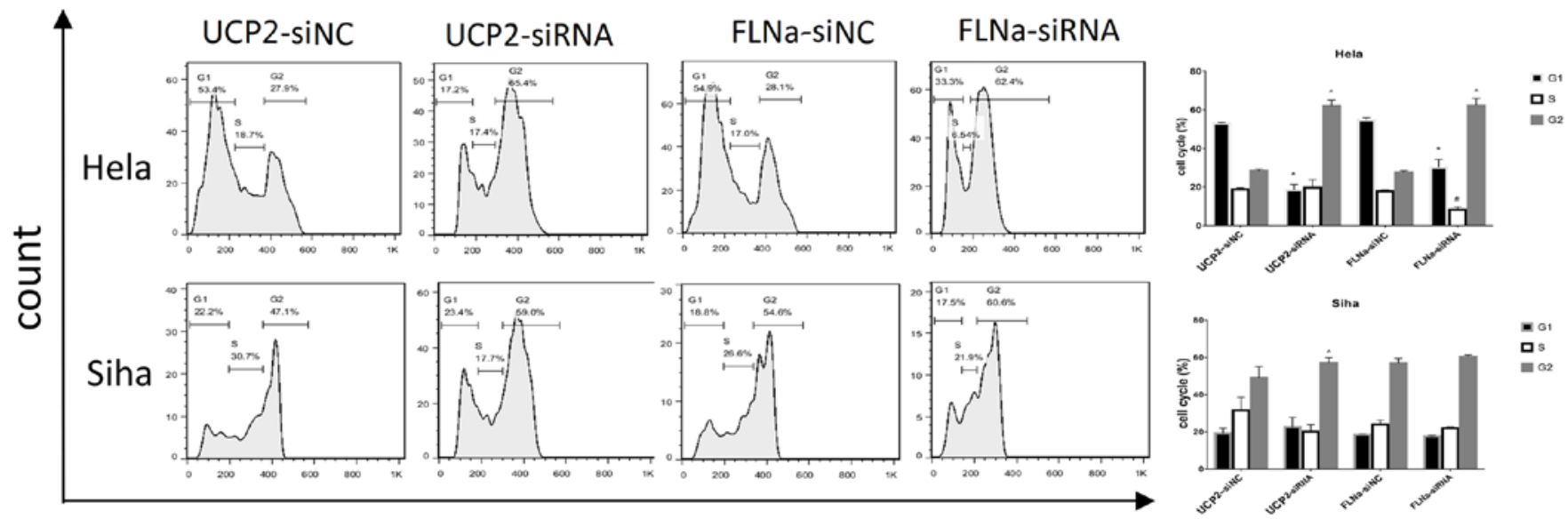

모

FL2-A

Figure 4. Representative images of flow cytometry. (A) Flow cytometry detection showed that there was no significant difference in apoptosis compared with the control groups. (B) Cell cycle detection. After UCP2 and FLNa knockdown in HeLa cells and UCP2 knockdown in SiHa cells, more cells were arrested at the $\mathrm{G}_{2}$ phase. Following UCP2 knockdown in SiHa cells G2 cells content increased. Following FLNa knockdown in SiHa cells, no significant cell cycle arrest was observed. ${ }^{*} \mathrm{P}<0.05,{ }^{* *} \mathrm{P}<0.01,{ }^{\#} \mathrm{P}<0.05,{ }^{\# \#} \mathrm{P}<0.01$; UCP2, uncoupling protein 2; FLNa, filamin A; SiNC, small interfering normal control; siRNA, small interfering RNA.

The present study showed that UCP2 was more advantageous for clinical staging and prediction of lymph node metastasis in patients with CC compared with p16/Ki67 dual staining.

Tumour development and progression depend on the activation state of signalling pathways that regulate cell proliferation and differentiation (34). Among the numerous signalling pathways associated with tumour development and progression, mitogen-activated protein kinase (MAPK) signalling is an important pathway. As the most important MAPK family member in mammalian cells, ERK is widely expressed in various tissues and is involved in the regulation of cell proliferation and differentiation. Abnormal activation of this signalling pathway leads to abnormal cell proliferation and differentiation, which are important steps in tumour development and progression $(35,36)$.

Loss of integrity of the extracellular matrix and basal membrane (mainly collagen, laminin and fibronectin; lytic enzymes can destroy these components) is an important step in tumour metastasis (37). MMPs consist of a large family of proteolytic enzymes, and their expression is increased in a number of malignant tumour types, cultured tumour cells and oncogene-transformed cells. In vitro experiments have demonstrated that a high invasion capacity of tumour cells is associated with increased expression of MMP-9 $(38,39)$. MMP-2 and MMP-9 are upregulated in CC and precancerous lesions, and studies have investigated the value of MMP-2 and MMP-9 overexpression in predicting cervical diseases (40).

In the present study, the effects and underlying mechanisms of FLN and UCP2 on the biological behaviour of cultured CC cell lines in vitro were investigated. Previous studies on FLNa, such as that by Zhu et al (41), demonstrated that FLNa regulates the Ras/ERK and Ras/guanine nucleotide exchange factor-1 pathways to decrease intracellular MMP-9, inhibit degradation of the extracellular matrix, and thereby prevent tumour cell migration, which is consistent with the findings of the present study. With regard to the mechanism underlying UCP2 in the 
A

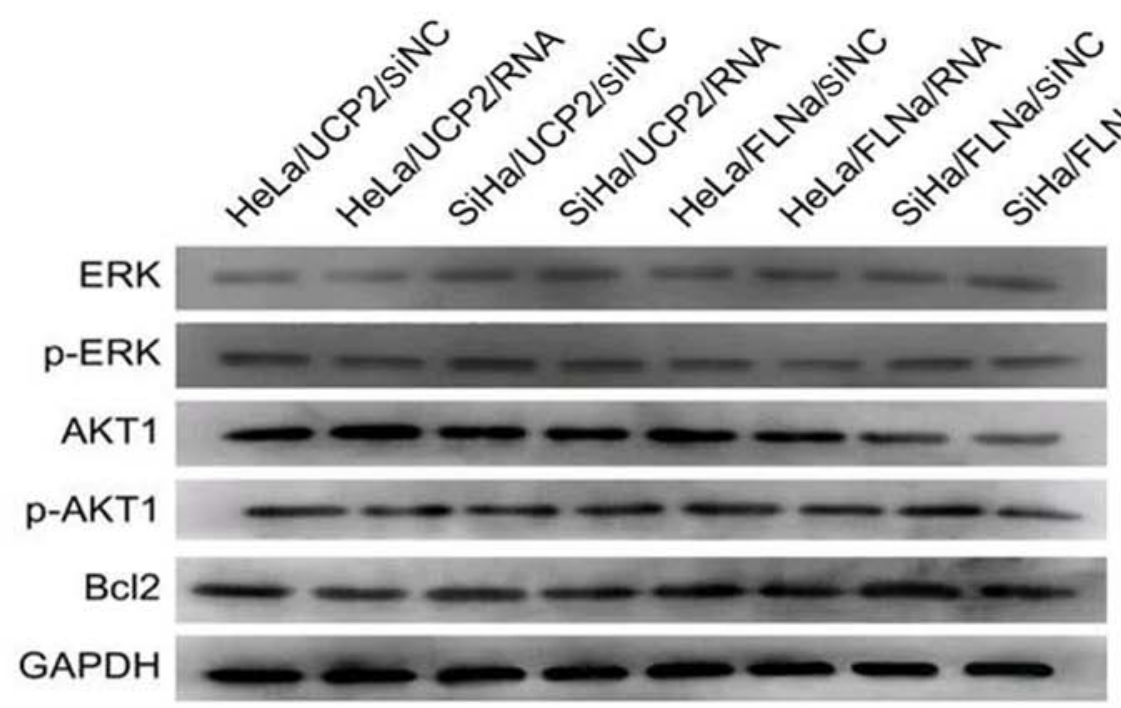

B

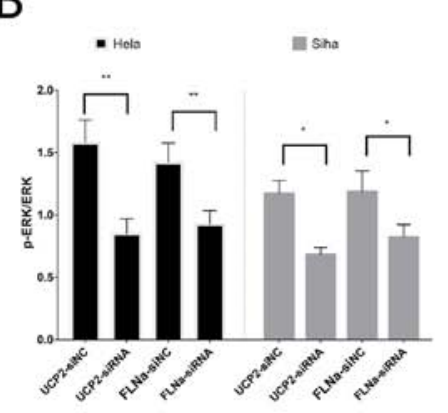

$E$

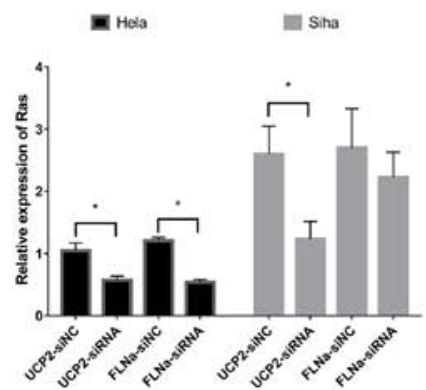

C

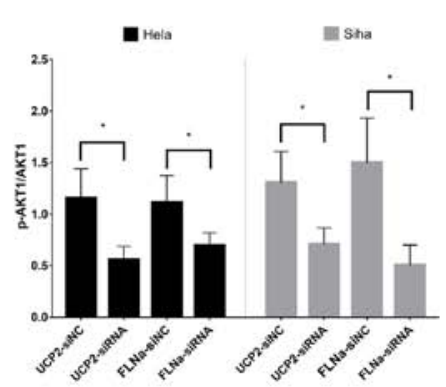

$\mathrm{F}$

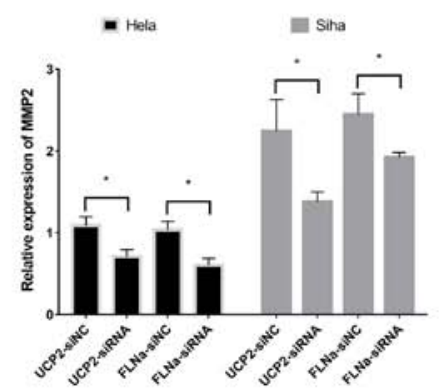

D

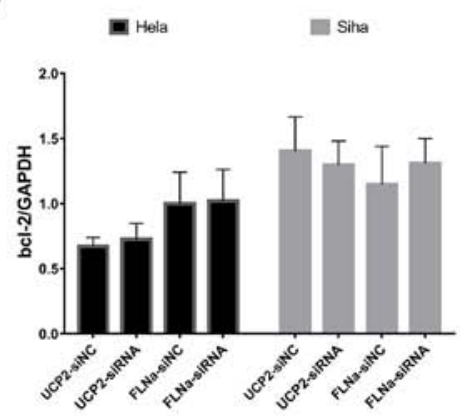

G

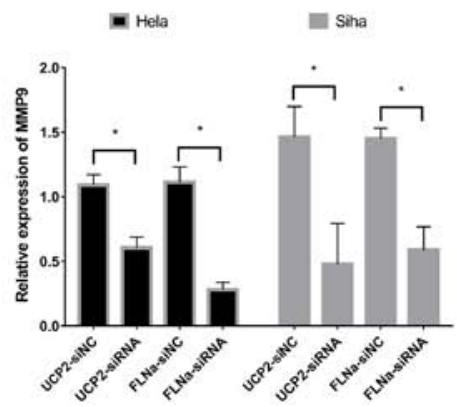

Figure 5. Investigation of the signalling pathways of UCP2 and FLNa. (A) Protein levels detected by western blotting, including ERK, p-ERK, AKT, p-AKT and Bcl-2. (B) After UCP2 and FLNa knockdown in HeLa and SiHa cells, p-ERK1/2 was downregulated; (C) p-AKT1 was downregulated; (D) there was no significant change in Bcl-2 expression; (E) the RAS mRNA levels were decreased in HeLa cells, but there was no significant change in SiHa cells; (F) MMP-2 mRNA levels were decreased; and (G) MMP-9 mRNA levels were decreased. ${ }^{*} \mathrm{P}<0.05 ;{ }^{* *} \mathrm{P}<0.01$. UCP2, uncoupling protein 2 ; FLNa, filamin A; ERK, extracellular signal-regulated kinase; p, phosphorylated; AKT, protein kinase B; Bcl-2, B-cell lymphoma-2.

development of colon cancer, it has been suggested that UCP2 may be involved in the development and progression of colon cancer by regulating the production of ROS, which then activate ERK1/2 and JNK1/2, resulting in hyperproliferation of intestinal epithelial cells (42). These studies suggest that FLNa and UCP2 play roles in tumour development and progression via the Ras/MAPK/ERK signalling pathway. Our results from cultured $\mathrm{CC}$ cell lines in vitro show that FLNa and UCP2 were mainly distributed in the cytoplasm of CC cells and that knockdown of FLNa or UCP2 slowed cancer cell proliferation, arrested the cells at the $G_{2}$ phase, with no significant apoptosis, and decreased cell migration and invasion, suggesting that FLNa or UCP2 knockdown affected the biological behaviour of CC cells by decreasing the expression levels of cell-associated proteins (such as p-ERK1/2 and p-AKT1) and the mRNA levels of Ras, MMP-2 and MMP-9. Taken together, these data suggest that FLNa and UCP2 play a role in tumour development and progression via the Ras/MAPK/ERK signalling pathway, which is consistent with findings of previous studies $(41,42)$.

Due to limitations of the experimental conditions, the present study did not analyse the tumourigenicity of FLNa or UCP2 in vitro. Several studies have demonstrated the roles of FLNa and 
UCP2 in the development of colon and prostate cancer. In the present study, in vitro experiments were performed with cultured $\mathrm{CC}$ cells and showed that FLNa and UCP2 play roles in the development and progression of CC via the Ras/MAPK/ERK signalling pathway. FLNa and UCP 2 are upregulated in CC cells and show relatively low expression levels in NC cells, reflecting the specificity of their high expression in CC. FLNa and UCP2 are superior to $\mathrm{p} 16$ and $\mathrm{Ki} 67$ for early prediction of the progression of HSIL to CC. FLNa expression levels were associated with and p16 expression levels, and may be used as indicators for this purpose. UCP2 is specific for clinical stage and lymph node metastasis and may be used as a prognostic indicator. Combined FLNa and UCP2 screening facilitates stratified management of patients. Particularly for patients who are UCP2-positive, the necessity for surgery should be re-evaluated.

The present study had a relatively small sample size; therefore, experimental data from studies with larger sample sizes are required to further validate the application of FLNa and UCP2 as clinical diagnostic strategies.

\section{Acknowledgements}

Not applicable.

\section{Funding}

The present study was supported by the National Key Research and Development Program of China (grant nos. 2016YFC1302900 and 2016YFC090290), the National Natural Science Foundation of China (grant no. 81572559), and the Key Research and Development Program of Shandong Province, China (grant nos. 2017CXGC1210 and 2015GSF118097).

\section{Availability of data and materials}

The datasets used and/or analysed during the present study are available from the corresponding author on reasonable request.

\section{Authors' contributions}

AW and YZ conceived and designed the experiments. AW performed the experiments, analysed the data and wrote the paper. LL, MY, SH and XY participated in the cell experiments. HZ and FL participated in the clinical research. All authors read and approved the final version of this manuscript.

\section{Ethics approval and consent to participate}

The present study was approved by the Ethics Committee of Qilu Hospital (approval no. KYLL-2017-560). All patients provided written informed consent prior to the study start.

\section{Patient consent for publication}

Not applicable.

\section{Competing interests}

The authors declare that they have no competing interests.

\section{References}

1. Torre LA, Bray F, Siegel RL, Ferlay J, Lortet-Tieulent J and Jemal A: Global cancer statistics, 2012. CA Cancer J Clin 65: 87-108, 2015

2. Bray F, Ferlay J, Soerjomataram I, Siegel RL, Torre LA and Jemal A: Global cancer statistics 2018: GLOBOCAN estimates of incidence and mortality worldwide for 36 cancers in 185 countries. CA Cancer J Clin 68: 394-424, 2018.

3. Chen W, Zheng R, Baade PD, Zhang S, Zeng H, Bray F, Jemal A, Yu XQ and He J: Cancer statistics in China, 2015. CA Cancer J Clin 66: 115-132, 2016.

4. Pecorelli S, Zigliani L and Odicino F: Revised FIGO staging for carcinoma of the cervix. Int J Gynaecol Obstet 105: 107-108, 2009.

5. Sedlis A, Bundy BN, Rotman MZ, Lentz SS, Muderspach LI and Zaino RJ: A randomized trial of pelvic radiation therapy versus no further therapy in selected patients with stage IB carcinoma of the cervix after radical hysterectomy and pelvic lymphadenectomy: A Gynecologic Oncology Group Study. Gynecol Oncol 73: 177-183, 1999.

6. Keys HM, Bundy BN, Stehman FB, Muderspach LI, Chafe WE, Suggs CL III, Walker JL and Gersell D: Cisplatin radiation and adjuvant hysterectomy compared with radiation and adjuvant hysterectomy for bulky stage IB cervical carcinoma. N Engl J Med 340: 1154-1161, 1999.

7. Nakamura K, Kitahara Y, Satoh T, Takei Y, Takano M, Nagao S, Sekiguchi I and Suzuki M: Analysis of the effect of adjuvant radiotherapy on outcomes and complications after radical hysterectomy in FIGO stage IB1 cervical cancer patients with intermediate risk factors (GOTIC Study). World J Surg Oncol 14: 173, 2016

8. Kim H, Park W, Kim YS and Kim YJ: Chemoradiotherapy is not superior to radiotherapy alone after radical surgery for cervical cancer patients with intermediate-risk factor. J Gynecol Oncol 31: e35, 2020.

9. Song S, Song C, Kim HJ, Wu HG, Kim JH, Park NH, Song YS, Kim JW, Kang SB and Ha SW: 20 year experience of postoperative radiotherapy in IB-IIA cervical cancer patients with intermediate risk factors: Impact of treatment period and concurrent chemotherapy. Gynecol Oncol 124: 63-67, 2012.

10. Ryu SY, Park SI, Nam BH, Cho CK, Kim K, Kim BJ, Kim MH, Choi SC, Lee ED and Lee KH: Is adjuvant chemoradiotherapy overtreatment in cervical cancer patients with intermediate risk factors? Int J Radiat Oncol Biol Phys 79: 794-799, 2011.

11. Jin YZ, Pei CZ and Wen LY: FLNA is a predictor of chemoresistance and poor survival in cervical cancer. Biomark Med 10: 711-719, 2016.

12. Imai K, Fukuda T, Wada T, Kawanishi M, Tasaka R, Yasui T and Sumi T: UCP2 expression may represent a predictive marker of neoadjuvant chemotherapy effectiveness for locally advanced uterine cervical cancer. Oncol Lett 14: 951-957, 2017.

13. Stossel TP, Condeelis J, Cooley L, Hartwig JH, Noegel A, Schleicher M and Shapiro SS: Filamins as integrators of cell mechanics and signalling. Nat Rev Mol Cell Biol 2: 138-145, 2001.

14. Robertson SP, Twigg SR, Sutherland-Smith AJ, Biancalana V, Gorlin RJ, Horn D, Kenwrick SJ, Kim CA, Morava E, Newbury-Ecob R, et al: Localized mutations in the gene encoding the cytoskeletal protein filamin A cause diverse malformations in humans. Nat Genet 33: 487-491, 2003.

15. Keshamouni VG, Michailidis G, Grasso CS, Anthwal S, Strahler JR, Walker A, Arenberg DA, Reddy RC, Akulapalli S, Thannickal VJ, et al: Differential protein expression profiling by iTRAQ-2DLC-MS/MS of lung cancer cells undergoing epithelial-mesenchymal transition reveals a migratory/invasive phenotype. J Proteome Res 5: 1143-1154, 2006.

16. Ai J, Huang H, Lv X, Tang Z, Chen M, Chen T, Duan W, Sun H, Li Q, Tan R, et al: FLNA and PGK1 are two potential markers for progression in hepatocellular carcinoma. Cell Physiol Biochem 27: 207-216, 2011.

17. Lin JF, Xu J, Tian HY, Gao X, Chen QX, Gu Q, Xu GJ, Song JD and Zhao FK: Identification of candidate prostate cancer biomarkers in prostate needle biopsy specimens using proteomic analysis. Int J Cancer 121: 2596-2605, 2007.

18. Larriba MJ, Martín-Villar E, Garcia JM, Pereira F, Peña C, de Herreros AG, Bonilla F and Muñoz A: Snail2 cooperates with snail1 in the repression of vitamin $D$ receptor in colon cancer. Carcinogenesis 30: 1459-1468, 2009. 
19. Flanagan LA, Chou J, Falet H, Neujahr R, Hartwig JH and Stossel TP: Filamin A, the Arp2/3 complex, and the morphology and function of cortical actin filaments in human melanoma cells. J Cell Biol 155: 511-517, 2001.

20. Zhang L, Komurov K, Wright WE and Shay JW: Identification of novel driver tumor suppressors through functional interrogation of putative passenger mutations in colorectal cancer. Int J Cancer 132: 732-737, 2013.

21. Zhang L, Kim S, Jia G, Buhmeida A, Dallol A, Wright WE, Fornace AJ, Al-Qahtani M and Shay JW: Exome sequencing of normal and isogenic transformed human colonic epithelial cells (HCECs) reveals novel genes potentially involved in the early stages of colorectal tumorigenesis. BMC Genomics 16 (Suppl 1): S8, 2015.

22. Pecqueur C, Alves-Guerra MC, Gelly C, Levi-Meyrueis C, Couplan E, Collins S, Ricquier D, Bouillaud F and Miroux B: Uncoupling protein 2 , in vivo distribution, induction upon oxidative stress, and evidence for translational regulation. J Biol Chem 276: 8705-8712, 2001.

23. Bo J, Xie S, Guo Y, Zhang C, Guan Y, Li C, Lu J and Meng QH: Methylglyoxal impairs insulin secretion of pancreatic beta-cells through increased production of ROS and mitochondrial dysfunction mediated by upregulation of UCP2 and MAPKs. J Diabetes Res 2016: 2029854, 2016.

24. Horimoto M, Resnick MB, Konkin TA, Routhier J, Wands JR and Baffy G: Expression of uncoupling protein-2 in human colon cancer. Clin Cancer Res 10: 6203-6207, 2004.

25. Berthiaume E, Derdak Z, Konkin TA, Resnick MB, Wands JR and Baffy G: Increased expression of uncoupling protein-2 in cholangiocarcinoma cells may confer resistance to apoptosis Hepatology 40: 372A-373A, 2004.

26. Sayeed A, Meng Z, Luciani G, Chen LC, Bennington JL and Dairkee SH: Negative regulation of UCP2 by TGF $\beta$ signaling characterizes low and intermediate-grade primary breast cancer. Cell Death Dis 1: e53, 2010.

27. Harper ME, Antoniou A, Villalobos-Menuey E, Russo A, Trauger R, Vendemelio M, George A, Bartholomew R, Carlo D, Shaikh A, et al: Characterization of a novel metabolic strategy used by drug-resistant tumor cells. FASEB J 16: 1550-1557, 2002.

28. Livak KJ and Schmittgen TD: Analysis of relative gene expression data using real-time quantitative PCR and the 2(-Delta Delta C(T)) method. Methods 25: 402-408, 2001.

29. Bray F, Carstensen B, Møller H, Zappa M, Zakelj MP, Lawrence G, Hakama M and Weiderpass E: Incidence trends of adenocarcinoma of the cervix in 13 European countries. Cancer Epidemiol Biomarkers Prev 14: 2191-2199, 2005.

30. Bray F, Loos AH, McCarron P, Weiderpass E, Arbyn M, Møller H, Hakama M and Parkin DM: Trends in cervical squamous cell carcinoma incidence in 13 European countries: Changing risk and the effects of screening. Cancer Epidemiol Biomarkers Prev 14: 677-686, 2005.
31. Bray F, Lortet-Tieulent J, Znaor A, Brotons M, Poljak M and Arbyn M: Patterns and trends in human papillomavirus-related diseases in Central and Eastern Europe and Central Asia. Vaccine 31: H32-H45, 2013.

32. Bedolla RG, Wang Y, Asuncion A, Chamie K, Siddiqui S, Mudryj MM, Prihoda TJ, Siddiqui J, Chinnaiyan AM, Mehra R, et al: Nuclear versus cytoplasmic localization of filamin A in prostate cancer: Immunohistochemical correlation with metastases. Clin Cancer Res 15: 788-796, 2009.

33. Yu LL, Chen W, Lei XQ, Qin Y, Wu ZN, Pan QJ, Zhang X, Chang BF, Zhang SK, Guo HQ and Qiao YL: Evaluation of p16/Ki-67 dual staining in detection of cervical precancer and cancers: A multicenter study in China. Oncotarget 7: 21181-21189, 2016.

34. Cairns RA, Harris IS and Mak TW: Regulation of cancer cell metabolism. Nat Rev Cancer 11: 85-95, 2011.

35. Niault TS and Baccarini M: Targets of raf in tumorigenesis. Carcinogenesis 31: 1165-1174, 2010.

36. Wong KK: Recent developments in anti-cancer agents targeting the Ras/Raf/MEK/ERK pathway. Recent Pat Anticancer Drug Discov 4: 28-35, 2009.

37. Watanabe H: Extracellular matrix-regulation of cancer invasion and metastasis. Gan To Kagaku Ryoho 37: 2058-2061, 2010 (In Chinese).

38. Ogata Y, Matono K, Nakajima M, Sasatomi T, Mizobe T, Nagase $\mathrm{H}$ and Shirouzu K: Efficacy of the MMP inhibitor MMI270 against lung metastasis following removal of orthotopically transplanted human colon cancer in rat. Int J Cancer 118: 215-221, 2006.

39. Lai WC, Zhou M, Shankavaram U, Peng G and Wahl LM: Differential regulation of lipopolysaccharide-induced monocyte matrix metalloproteinase (MMP)-1 and MMP-9 by p38 and extracellular signal-regulated kinase $1 / 2$ mitogen-activated protein kinases. J Immunol 170: 6244-6249, 2003.

40. Rauvala M, Aglund K, Puistola U, Turpeenniemi-Hujanen T, Horvath G, Willén R and Stendahl U: Matrix metalloproteinases-2 and -9 in cervical cancer: Different roles in tumor progression. Int J Gynecol Cancer 16: 1297-1302, 2006.

41. Zhu TN, He HJ, Kole S, D'Souza T, Agarwal R, Morin PJ and Bernier M: Filamin A-mediated down-regulation of the exchange factor Ras-GRF1 correlates with decreased matrix metalloproteinase-9 expression in human melanoma cells. J Biol Chem 282: 14816-14826, 2007.

42. Derdak Z, Mark NM, Beldi G, Robson SC, Wands JR and Baffy G: The mitochondrial uncoupling protein-2 promotes chemoresistance in cancer cells. Cancer Res 68: 2813-2819, 2008.

This work is licensed under a Creative Commons Attribution-NonCommercial-NoDerivatives 4.0 International (CC BY-NC-ND 4.0) License. 